\title{
REPORT ON THE DEATH OF AN OKAPI
}

by

\author{
G. M. SMITS, W. MISDORP and E. F. JACOB I 1)
}

The okapi (Okapia johnstoni Scl.) (Fig. 1) is a close relative of the giraffe and lives in tropical equatorial forest regions of central Africa. It was first recorded by Sir Harry Johnston in McClure's Magazine in 1901. While it is a comparatively rare mammal its survival seems certain as long as the virgin forest within which it lives remains untouched. It appears to have few natural enemies and man cannot use cars in hunting in this habitat.

Antwerp Zoo received the first okapi to leave Africa, in 1919. It survived only seven weeks. In 1931 the first pair ever to go into captivity were received in Antwerp Zoo: again, it was at Antwerp Zoo that the first calf was born (1954) but unhappily it was killed by its mother. The first okapi calf successfully to be reared was born in Vincennes Zoo, (Parc Zoologique de Vincennes) in Paris. Up to 1963 the total number of okapis to be born and reared in zoological gardens amounted to 23 known cases, thus indicating that breeding these animals in captivity is feasable. Gijzen and Montelmans (1962) report that the present number of okapis in captivity in zoos throughout the world is the comparatively small number of 60 .

This report deals with the male and female okapis that arrived in Amsterdam Zoo (Artis) in March 1962. The female (Anabella) was caught in July 1961 at Babesoa in the African Congo at the approximate age of two to three years. She stayed first of all for six months in the Duisburg Zoo and subsequently travelled together with the male (Aloto) to the Amsterdam Zoo. Approximately three years later, after an illness of one week, the female contracted an

1 Drs. G. M. Smits, Veterinary Surgeon of the Royal Zoological Society Natura Artis Magistra, Amsterdam.

Dr. W. Misdorp, Inspector-veterinarian-bacteriologist of the Amsterdam abattoir, member of the staff of the Netherlands Cancer Institute, Amsterdam.

Dr. E. F. Jacobi, Zoologist, director of the Royal Zoological Society Natura Artis Magistra, Amsterdam. acute serious illness and died (August 1964). The literature concerned with the illness and disease of the okapi is comparatively sparse and it was considered sensible to report the details effecting the death of one and the illness of the other of these two okapis.

\section{CLINICAL EXAMINATION}

When examined by one of us (G.M.S.) on the 24th August, 1964, the female Anabella appeared to have departed from her previous excellent health. She was standing in her outside enclosure dozing with half-closed eyes. Twenty-four hours later she was trembling, and discharging a liquid from both nostrils. Her breathing was jerky. A tentative diagnosis of rhinitis perhaps with pneumonitis, was made and penicillin ( 1 million i.u.) and streptomycin $(1,650 \mathrm{mg}$ ) was injected by flying syringe daily, together with $2 \mathrm{ml}$ of dexamethason (= opticortenol; Ciba). The condition of the animal deteriorated during the next twenty-four hours and she was seen to eat or drink practically nothing. By the 27th of August (three days after the commencement of the illness) there was a heavy mucous discharge from both nostrils and blood clots were occasionally seen in the discharge. Respirations were rapid and shallow and audible.

Therapy was altered on the 27th of August because there was no response, and the penicillin/streptomycin/dexamethason routine was exchanged for a daily injection of $2,000 \mathrm{mg}$ of tetracycline, again given intramuscularly via the syringe ejector pistol. The following day (August 28th) the animal was also examined by two veterinary surgeons from the Internal Diseases Clinic of the Veterinary Faculty of Utrecht University (Drs. H. C. KALSBEEK and Dr. J. Kroneman). It was now possible to approach the animal and take its temperature which was $39.5^{\circ}$ centigrade per rectum, and following the consultation with Kalsbeex and Kroneman a higher dosage of 
penicillin/streptomycin was administered and from August 28th a daily dose of 3 million i.u. procaine penicillin and 5 grams dihydrostreptomycin was administered. Dioxyanthrachinon (isticine) in honey was put on the animal's skin as a lick in the hope that this would stimulate the activities of the gastric and intestinal mucouse membrane, but the animal proved to be too ill even to lick its own coat. By the 30th of August the okapi's condition had deteriorated seriously and dyspnoea was evident together with the audible panting and wheezing. Rumenal contents were now seen to be continually discharging through the nostrils and the mouth but in spite of the animal's weakness it was not possible to carry out a tracheotomy. The animal died on August 30th at 4.30 p.m.

\section{PATHOLOGIST'S REPORT}

When the post-mortem was conducted (W.M.) the carcass was observed to be well nourished.

1. Reproductive Organs. The uterus contained a well developed female embryo.

2. Intestinal Tract. The rumen showed fibrous tissue connections with the diaphragm (as did the spleen and the liver).

3. The Liver. The liver was attached to the diaphragm by fibres of connective tissue and one of the intrahepatic bile ducts was enlarged and had a thickened wall. The liver itself was enlarged and discoloured.

4. The Spleen. The spleen was flaccid, and connected to the diaphragm and to the liver by fibres of connective tissue.

5. The Heart. The outer layer of the pericardium was entirely covered with strands of connective tissue, whilst on the epicardium itself there were fibrinous flakes and blood clots.

6. Respiratory System. The mucosa of the larynx was dark red and covered with food remnants, whilst the tonsils and retropharyngeal lymphatic glands were enlarged, soft and dark red. (A direct smear from the tonsils and retropharyngeal lymphatic glands yielded a great many gram-negative rodbacilli, yielding Escherichia coli). The trachea and large bronchi showed a heavily injected mucosa, whilst entering the bronchus into left pulmonary vein there were fresh food particles. The lungs showed considerable changes - in the dorsal lobes there were bluish-purplish solidifying areas.

Microscopic examination of lung tissue demonstrated gross abnormalities particularly in the dorsal lobes, where an accumulation of serous and fibrinous deposits had thickened grossly the septa (Fig. 2). The alveoli were filled with a serofibrinous exudate. Many bronchi (Fig. 3) contained large quantities of leucocytes with polymorphic nuclei showing signs of degeneration (karyopycnosis, karyorrhexis.). Strands of a leucocytic infiltration were present in the peribronchial region. Perivascular infiltration of plasma cells and lymphocytes had occurred in heart muscle and particularly in the liver.

\section{DIAGNOSIS}

The combined results of the macroscopic and microscopic examination indicate the following conditions: acute laryngitis, tonsilitis, tracheo-bronchitis, serofibrinous pneumonia, subacute to subchronic myocarditis and hepatitis. It is believed that the connective tissue fibres found on the rumen, diaphragm, liver, spleen and pericardium, may have been caused by a foreign body penetrating the anterior wall of the rumen but such could not be traced at the post-mortem.

\section{BACTERIOLOGICAL EXAMINATION}

The following organs were examined (J.L.H.1)) in aerobic and anaerobic cultures: spleen, liver, kidney, lungs (lung parenchyma and pus from the bronchi). From all these cultures two strains of Escherichia coli were obtained, one a standard strain, and one a lactosenegative strain. Both were tested for anitibiotics and sensitivity and the following tables show the results.

$$
+=\text { sensitive }
$$

Standard strain E. coli ampicillin streptomycin tetracycline chloramphenicol kanamycin

+
0
0
+
+

$$
\mathrm{O}=\text { non sensitive }
$$
Lactose-negative E. coli ampicillin streptomycin tetracycline chloramphenicol kanamycin

\section{PARASITOLOGICAL EXAMINATION}

Upon its arrival at Artis, the animal had been shown (A.C.R.2)) to have been heavily infected with intestinal parasites. Treatment with mintic and thiabendazol was extremely successful, as confirmed by subsequent faecal examinations at a period of months. ${ }^{3}$ )

1 Dr. J. L. Hoogendijk, Bacteriologist, Head of the Department of Bacteriology of the Wilhelmina Hospital, Amsterdam.

2 Miss A. C. Rijpstra, Parasitological technologist attached to the Institute of Tropical Hygiene and Geographical Pathology of the Royal Institute for the Tropics, Amsterdam.

A A detailed report on this treatment will be published elsewhere. 


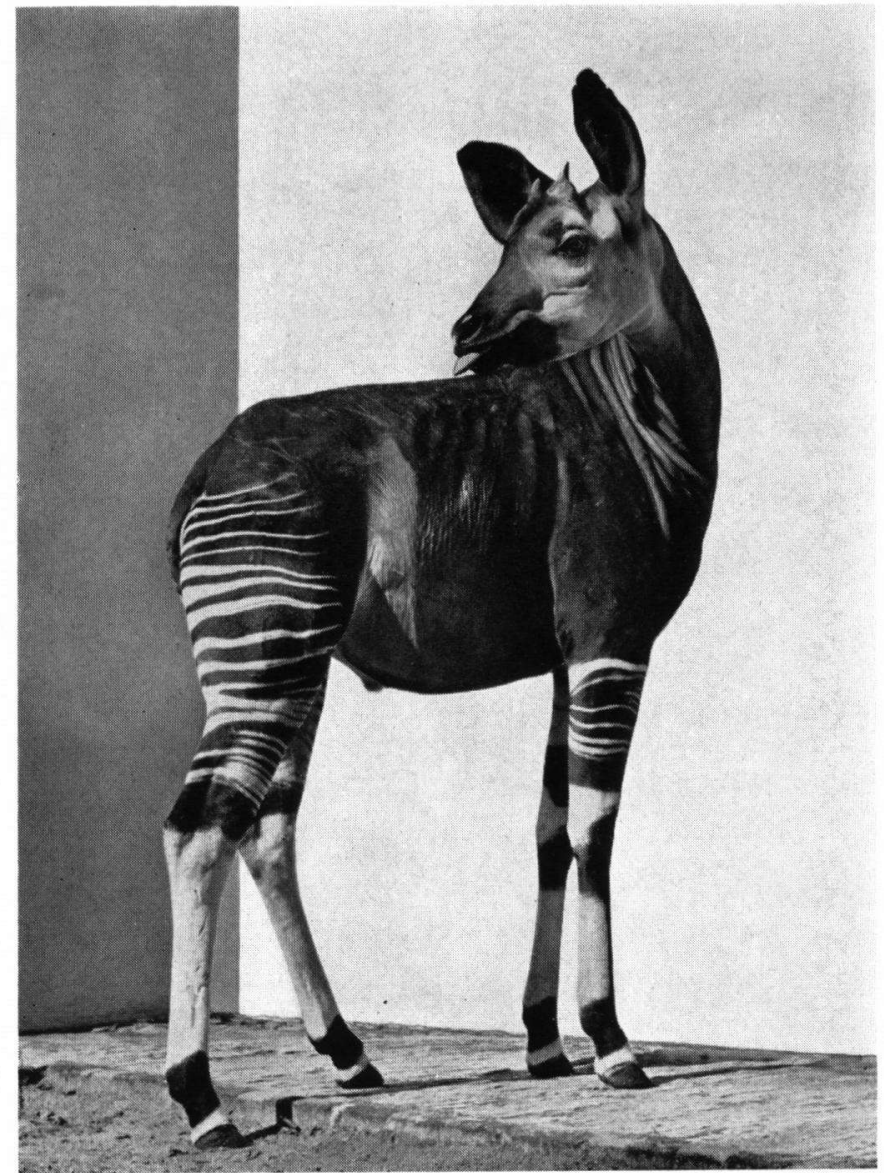

Fig. 1. Male Okapi.

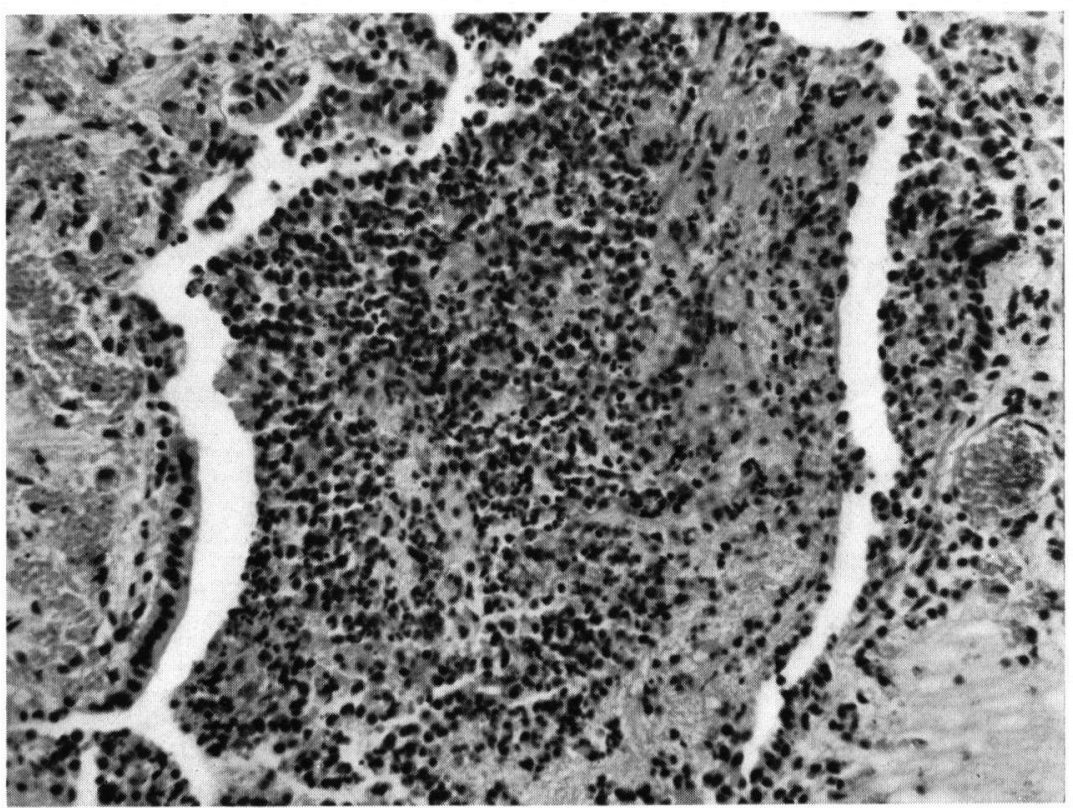

Fig. 2. Purulent bronchitis. 


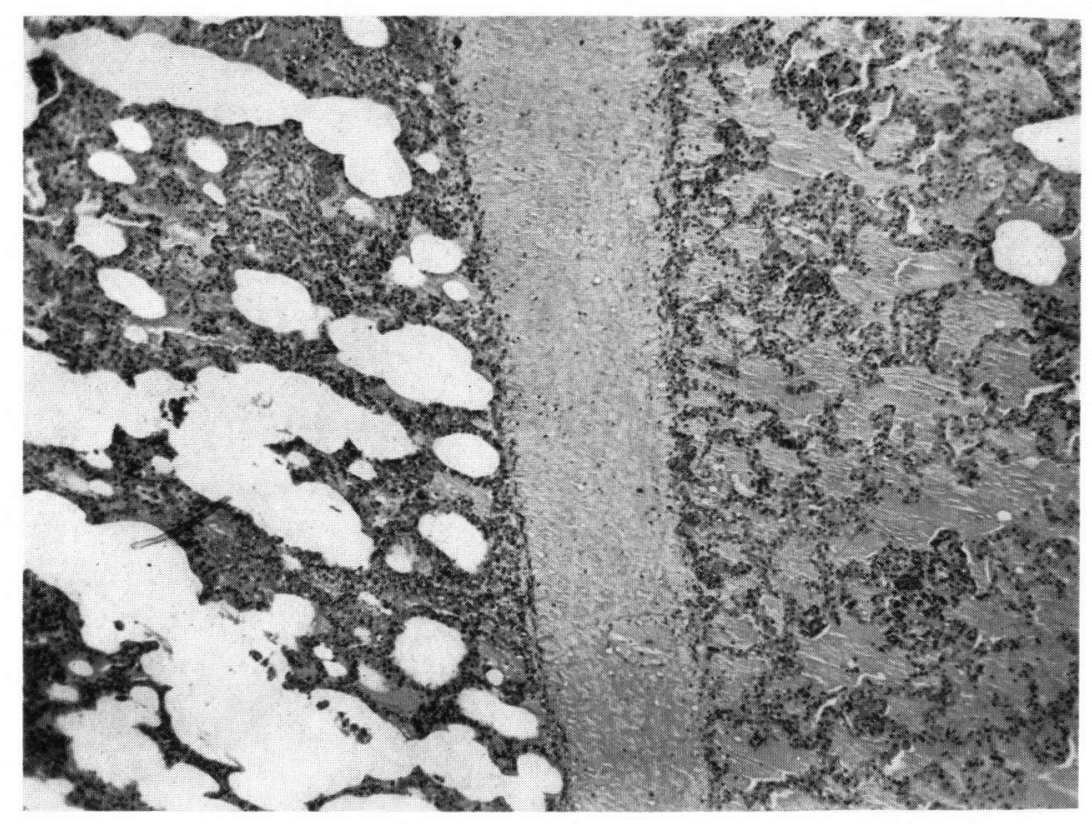

Fig. 3. Edematous pulmonary septa, Alveols containing edema-fluid. 
At che post-mortem, stomach and intestine were taken and thoroughly rinsed. The parasitological examination of the wall of these organs together with the rinsing liquid, showed that there was no infestation which is in support of the negative faecal examinations.

In one part of the liver some specimens of the Nematode Monodontella giraffae were found.

\section{ILLNESS OF THE MALE OKAPI ALOTO}

A few days after the death of the female okapi it was noticed that the male (Aloto) was somewhat off his food (September 3rd). In view of the information now available, and although no other clinical signs were presented, combined penicillin/streptomycin therapy was started (September 4th). It was soon after these drugs had been administered that the precise result of the bacteriological examination of the dead female (Anabella) were received and in view of the sensitivities exhibited by the examination, ampicillin was administered in stead, $(2 \times 2,500 \mathrm{mg}$ per day) all drugs being given, of course, by the capchur gun.

On September the 6th and 7th the animal hardly ate or drank and appeared to be quite ill, but on the 9th of September the okapi resumed eating, drinking and ruminating and appeared to get stronger every day. On September the 14th the last injection was administered and further therapy withdrawn.

\section{DISCUSSION}

According to Gijzen (1959) between 1919 and 1959, 137 okapis had been kept in captivity in zoological gardens throughout the world of these, 35 had had their cause of death recorded. Of this number, 14 showed a heavy infestation of intestinal parasites including symptoms of anaemia, colic, and cirrhosis of the liver. 10 animals were noted to have died from injuries which proved fatal, amongst the other causes of death were infections deriving from the intestines, generalized tuberculosis (2) and nagana. There was a suspicion that 2 animals had been poisoned by strychnine, and a further 2 animals presented serious clinical signs assumed to be "heart-attacks". There is only one previous record of 2 animals showing an infection of the respiratory tract with pneumonia. A recent publication deals with an outbreak of smallpox in Copenhagen Zoo involving 4 okapis (Basse, Freundt and Hansen, 1964). In this interesting outbreak amongst the clinical signs were a dozing attitude, lack of appetite and fever, followed by a mucopurulent discharge from the nostrils together with coughing. There was also swelling and stenosis of the lungs. Penicillin/streptomycin and tetracyclin therapy was of no avail and the youngest okapi died. The post-mortem revealed papular ulcerative and necrotic changes in the mucous membrane of the mouth and the throat, and oesophagus. There was also a mucopurulent necrotic tracheobronchitis together with a bi-lateral pneumonia. A detailed examination of post-mortem material established that the lesions were caused by a smallpox virus.

It is interesting to notice that some of the clinical and pathological findings related to "Anabella" correspond to those seen by the Danish workers. The establishment of the Escherichia coli infections confirm that a coliform septicemia did exist but it is interesting to conjecture the possibility that a primary virus infection had occurred. The fact that no papular lesions were discovered in the epithelium at post-mortem does not necessarily exclude a primary virus infection.

Similarly the male (Aloto) may also have suffered a virus infection which may not have proceeded to secondary invasion. At the same time, and remembering the bacteriological report from "Anabella", it seemed logical to treat the male with ampicilline and it must be emphasized that the rapidly available sensitivity test results were of great use.

It is interesting, too, that the post-mortem parasitological examinations bore out the negative nature of the faecal checks carried out upon the living animal.

The authors wish to acknowledge the help received from Dr. J. L. HoogendiJK, Miss A. C. RujpSTRA and Dr. P. ZwART, of Utrecht, and wish to thank Dr. Oliver Graham-Jones, senior veterinary officer of the Zoological Society of London, for rewriting the English text.

\section{SUMMARY}

A six to seven year-old female okapi died after a week of illness showing clinical signs of an acute infection of the respiratory tracts. Antibiotic therapy did not influence the course of the disease. The postmortem examination demonstrated the presence of acute laryngitis, tonsilitis, tracheo-bronchitis, bronchopneumonia and serifibrinous exudate, together with a subacute and subchronic myocarditis and hepatitis. Bacteriological cultures from the spleen, liver, kidneys, and the lungs, yielded two strains of Escherichia coli.

Forty-eight hours after the death of the female, the male okapi became ill and it was treated with 
antibiotics indicated by the sensitivity tests carried out upon the Escherichia coli noted in the dead female: ampicilline was thus injected into the male whose health gradually improved and a complete recovery occurred.

\section{ZUSAMMENFASSUNG}

Ein 6 bis 7-järiges weibliches Okapi starb nach einwöchiger Krankheit under den Symptomen einer akuten Infektion der Luftwege. Eine Behandlung mit Depomycin (Depot Penicillin-Streptomycin) und Terramycin war ohne Erfolg.

Die pathologisch-anatomische Untersuchung ergab eine akute Laryngitis, Tonsillitis, Tracheobronchitis, Peribronchitis und serofibrinöse Pneumonie, nebst einer subakut-subchronischen Myocarditis und Hepatitis. Aus Milz, Leber, Nieren und Lungen wurden zwei E-coli-Stämme kultiviert. Zwei Tage nach dem Tode des Weibchens erkrankte auch das Männchen. $\mathrm{Da}$ es sich inzwischen herausgestellt hatte, dass die beiden aus dem infektiösen Material des Weibchens isolierten E-coli-Stämme gegen Ampicillin (= Penbritin) empfindlich waren, wurde dieses Antibiotikum auch für die Behandlung des Männchens angewendet. Das Tier erholte sich schnell und ist bis heute gesund geblieben.

\section{RESUME}

Un okapi femelle âgé de 6 à 7 ans meurt après avoir, pendant une semaine, présenté les symptômes d'une infection aiguë des voies respiratoires. On lui a appliqué sans succès un traitement à base de Terramycine et de Depomycine (Depot-Penicilline-Streptomycine). L'examen anatomopathologique a révélé des lésions de laryngite aiguë, d'amygdalite, de trachéo-bronchite, de péribronchite et de pneumonie sérofibrineuse, ainsi que des lésions de myocardite subaiguë chronique et d'hépatite. On a pu isoler de la rate, du foie, des reins et des poumons deux souches d'Escherichia coli.

Le mâle est tombé malade deux jours après la mort de la femelle alors qu'une étude des souches isolées de celle-ci avait révélé leur sensibilité à l'Ampicilline (Penbritin). L'emploi de cet antibiotique a permis de sauver le mâle qui s'est rétabli assez vite et paraît encore aujourd'hui en bonne santé.

\section{LITERATURE}

Basse, A., Freundt, E. A., Hansen, F., 1964: Ein Ausbruch von Pockenkrankheit bei Okapi's im Kopenhagen Zoo. VI Internationales Synposium über die Erkrankungen der Zootiere, 54.
Gijzen, A., 1959: Das Okapi. Die neue Brehm-Bücherei. A. Zeinesen Verlag. Wittenberg Lutherstadt.

GiJzen A. et Mortelmans J., 1962: Notice complémentaire sur l'okapi. Bull. Soc. Royale de Zool. d'Anvers. 